\title{
The Effect of Fermentation on the Diosgenin Content of Dioscorea Tubers
}

\author{
B. Roark, ${ }^{1}$ H. Cruzado, ${ }^{2}$ H. Delpin, ${ }^{2}$ and M. P. Morris ${ }^{3}$ \\ INTRODUCTION
}

Diosgenin is the material employed for the preparation of several widely used pharmaceutical products. It can be isolated readily from several species of Dioscorea tubers. This steroid is the basis of an industry that each year fabricates products valued at more than $\$ 50,000,000$. The wild, high-yielding tubers of commerce are native to Mexico and Central America, and have not yet been domesticated. Other high-yielding species of wild tubers are native to Africa. The domestication program here in Puerto Rico has been in progress for several years. The outlook is very promising.

\section{PROCEDURES AND RESULTS}

All of the commercial producers of diosgenin use essentially the same process for its isolation from wild Dioscorea tubers. This consists of three operations: 1, Maceration and fermentation of the tubers; 2 , acid hydrolysis of the fermented mixture; 3 , extraction of the diosgenin with petroleum ether.

The fermentation step has been an important part of the standard isolation procedure for almost 20 years. Its use is based on the belief that fermentation increases the amount of diosgenin that can be isolated from the tubers. This paper describes a study of the fermentation procedure, and presents data which illustrate for the first time the true effects of fermentation on diosgenin content.

Fresh tubers, 2 years old and weighing 30 pounds, were sliced, divided into three equal portions, and then homogenized with an equal weight of water in a high-speed blender for 5 minutes. The macerated tubers were then placed in 10-gallon porcelain pots. The total weight, the percentage moisture, and the total diosgenin were recorded for each pot. The pots were then stored for 7 days at $30^{\circ} \mathrm{C}$. in a dark room. At the end of 7 days the contents of one pot were weighed and analyzed 4 . After fermenting for 2 weeks the contents of the second pot were analyzed, and the contents of the third jar

1 Plant Physiologist, Federal Experiment Station, Mayagüez, P.R. Present address Agricultural Experiment Station, Stoneville, Miss.

${ }^{2}$ Agronomists, Federal Experiment Station, Mayagüez, P.R.

${ }^{3}$ Chemist, Federal Experiment Station, Mayaguez, P.R. Present address Division of Food, Food and I)rug Administration, Washingt on 25, 1). C.

${ }^{4}$ Rothrock, J. W., Hammes, l'. A., and MeAleer, W. J., Ind. Eng. Chem., 49, 18088, 1957. 
were analyzed after fermenting for 3 weeks. This experiment was repeated three times with both Dioscorea composita and $D$. floribunda. The results of all experiments were for all practical purposes the same. Typical data are presented in table 1.

TABLE 1.-Fresh weight, dry weight, and diosgenin contents (grams) of 2 species of Dioscorea after various treatments

\begin{tabular}{l|c|c|c|c|c|c}
\hline \multicolumn{1}{c|}{ Treatment of fresh tuber before analysis } & \multicolumn{3}{|c|}{ D. composila } & \multicolumn{3}{|c}{ D. Aoriburnda } \\
\cline { 2 - 5 } & $\begin{array}{c}\text { Fresh } \\
\text { weight }\end{array}$ & $\begin{array}{c}\text { Dry } \\
\text { weight }\end{array}$ & $\begin{array}{c}\text { Total } \\
\text { diosgenin }\end{array}$ & $\begin{array}{c}\text { Fresh } \\
\text { weight }\end{array}$ & $\begin{array}{c}\text { Dry } \\
\text { weight }\end{array}$ & $\begin{array}{c}\text { Total } \\
\text { diosgenin }\end{array}$ \\
\hline 1, Sliced, dried, and ground & 600 & 197.6 & 5.2 & 600 & 200.0 & 5.5 \\
2, Homogenized, dried, and ground & 600 & 200.0 & 8.4 & 600 & 204.0 & 8.9 \\
3, Homogenized and fermented 7 days & 600 & 183.6 & 8.2 & 600 & 198.3 & 8.9 \\
4, Homogenized and fermented 14 days & 600 & 182.5 & $\mathbf{8 . 3}$ & 600 & 174.7 & 8.5 \\
5, Homogenized and fermented 21 days & 600 & 180.4 & 7.6 & 600 & 173.4 & 8.0 \\
6, Homogenized and fermented 28 days & 600 & 175.5 & 7.0 & 600 & 149.3 & 7.6 \\
\hline
\end{tabular}

\section{DISCUSSION}

The data show that the total weight of diosgenin in the fresh tubers is not changed by fermentation periods extending up to 21 days. It will be noted that the percentage of diosgenin apparently increases during fermentation. It is obvious, however, that this increase does not reflect a change in the quantity of diosgenin present, but rather indicates a decrease in the dry weight of total solids. The data show that fermentation does not increase the weight of diosgenin present in Dioscorea tubers.

\section{SUMMARY}

The total weight of diosgenin in fresh Dioscorea tubers remains unchanged during fermentation periods of up to 21 days, but the percentage of diosgenin seemingly increases. This apparent increase is attributed to a decrease in the dry weight of total solids present only.

\section{RESUMEN}

Los datos experimentales muestran que el peso total de diosgenina en los tubérculos frescos de Dioscorea no cambia durante el período de fermentación. Se nota que el porcentaje de diosgenina aumenta durante la fermentación. Por otra parte, este aumento no depende de un cambio de la cantidad de diosgenina presente, sino del peso seco de los sólidos totales, el cual disminuye. Por consiguiente, los datos experimentales muestran que la fermentación no aumenta el peso de diosgenina presente en los tubérculos de Dioscorea. 